\title{
INEQUALITIES FOR GENERALIZED TRIGONOMETRIC AND HYPERBOLIC FUNCTIONS WITH ONE PARAMETER
}

\author{
MiaO-Kun Wang, Miao-Ying Hong, Yang-Fan Xu, Zhong-Hua Shen And \\ YU-MING CHU
}

Abstract. In the article, we establish several new inequalities for the generalized trigonometric and hyperbolic functions with one parameter, generalize the well known Mitrinović-Adamović, Lazarević, Huygens-type, Wilker-type and Cusa-Huygens-type inequalities to the cases of the generalized trigonometric and hyperbolic functions with one parameter.

Mathematics subject classification (2010): 33B10, 26D05.

Keywords and phrases: Generalized trigonometric function, generalized hyperbolic function, Gamma function, Mitrinović-Adamović inequality, Lazarević inequality, Huygens-type inequality, Wilker-type inequality, Cusa-Huygens-type inequality.

\section{REFERENCES}

[1] M. Adil Khan, Y.-M. Chu, A. Kashuri, R. Liko And G. Ali, Conformable fractional integrals versions of Hermite-Hadamard inequalities and their generalizations, J. Funct. Spaces, 2018 (2018), Article ID 6928130, 9 pages.

[2] M. Adil Khan, Y.-M. Chu, T. U. Khan and J. Khan, Some new inequalities of HermiteHadamard type for s-convex functions with applications, Open Math., 15, 1 (2017), 1414-1430.

[3] M. Adil Khan, M. Hanif, Z. A. Khan, K. Ahmad and Y.-M. Chu, Association of Jensen's inequality for s-convex function with Csiszár divergence, J. Inequal. Appl., 2019 (2019), Article 162, 14 pages.

[4] M. Adil Khan, A. Iqbal, M. Suleman and Y.-M. Chu, Hermite-Hadamard type inequalities for fractional integrals via Green's function, J. Inequal. Appl., 2018 (2018), Article 161, 15 pages.

[5] M. Adil Khan, Y. Khurshid, T.-S. Du And Y.-M. Chu, Generalization of Hermite-Hadamard type inequalities via conformable fractional integrals, J. Funct. Spaces, 2018 (2018), Article ID 5357463, 12 pages.

[6] M. Adil Khan, S.-H. Wu, H. Ullah And Y.-M. Chu, Discrete majorization type inequalities for convex functions on rectangles, J. Inequal. Appl., 2019 (2019), Article 16, 18 pages.

[7] M. Adil Khan, S. Zaheer Ullah And Y.-M. ChU, The concept of coordinate strongly convex functions and related inequalities, Rev. R. Acad. Cienc. Exactas Fís. Nat. Ser. A Mat. RACSAM, 113, 3 (2019), 2235-2251.

[8] G. D. Anderson, M. K. Vamanamurthy and M. Vuorinen, Conformal Invariants, Inequalities, and Quasiconformal Maps, John Wiley \& Sons, New York, 1997.

[9] Ö. BAKŞI, P. GURKA, J. LANG AND O. MÉNDEZ, Basis properties of Lindqvist-Peetre functions on $L^{r}(0,1)^{n}$, Rev. Mat. Complut., 30, 1 (2017), 1-12.

[10] Á. BARICZ, B. A. BhaYo AND M. VuORINEN, Turán inequalities for generalized inverse trigonometric functions, Filomat, 29, 2 (2015), 303-313.

[11] B. A. Bhayo AND M. VuORInen, On generalized trigonometric functions with two parameters, J. Approx. Theory, 164, 10 (2012), 1415-1426.

[12] Z.-W. CAI, J.-H. HuAng AND L.-H. HUAnG, Generalized Lyapunov-Razumikhin method for retarded differential inclusions: applications to discontinuous neural networks, Discrete Contin. Dyn. Syst., 22B, 9 (2017), 3591-3614. 
[13] Z.-W. CAI, J.-H. Huang And L.-H. HuAng, Periodic orbit analysis for the delayed Filippov system, Proc. Amer. Math. Soc., 146, 11 (2018), 4667-4682.

[14] Y.-M. Chu, M. Adil Khan, T. Ali And S. S. Dragomir, Inequalities for $\alpha$-fractional differentiable functions, J. Inequal. Appl., 2017 (2017), Article 93, 12 pages.

[15] Y.-M. CHU, M.-K. WANG AND S.-L. QIU, Optimal combinations bounds of root-square and arithmetic means for Toader mean, Proc. Indian Acad. Sci. Math. Sci., 122, 1 (2012), 41-51.

[16] Z.-F. DAI, Comments on a new class of nonlinear conjugate gradient coefficients with global convergence properties, Appl. Math. Comput., 276 (2016), 297-300.

[17] Z.-F. DAI, X.-H. ChEN AND F.-H. Wen, A modified Perry's conjugate gradient method-based derivative-free method for solving large-scale nonlinear monotone equations, Appl. Math. Comput., 270 (2015), 378-386.

[18] Z.-F. DAI, D.-H. LI AND F.-H. WEN, Worse-case conditional value-at-risk for asymmetrically distributed asset scenarios returns, J. Comput. Anal. Appl., 20, 2 (2016), 237-251.

[19] Z.-F. DAI AND F.-H. WEN, Another improved Wei-Yao-Liu nonlinear conjugate gradient method with sufficient descent property, Appl. Math. Comput., 218, 14 (2012), 7421-7430.

[20] Z.-F. DAi AND F.-H. Wen, Robust CVaR-based portfolio optimization under a genal affine data perturbation uncertainty set, J. Comput. Anal. Appl., 16, 1 (2014), 93-103.

[21] L. DuAn, X.-W. FAng AND C.-X. HuAnG, Global exponential convergence in a delayed almost periodic Nicholson's blowflies model with discontinuous harvesting, Math. Methods Appl. Sci., 41, 5 (2018), 1954-1965.

[22] L. DUAN AND C.-X. HuAng, Existence and global attractivity of almost periodic solutions for a delayed differential neoclassical growth model, Math. Methods Appl. Sci., 40, 3 (2017), 814-822.

[23] L. Duan, L.-H. Huang, Z.-Y. Guo And X.-W. FAng, Periodic attractor for reaction-diffusion high-order Hopfield neural networks with time-varying delays, Comput. Math. Appl., 73, 2 (2017), 233-245.

[24] D. E. Edmunds, P. Gurka And J. LAng, Properties of generalized trigonometric functions, J. Approx. Theory, 164, 1 (2012), 47-56.

[25] X.-P. FAng, Y.-J. Deng And J. Li, Plasmon resonance and heat generation in nanostructures, Math. Methods Appl. Sci., 38, 18 (2015), 4663-4672.

[26] X-H. He, W.-M. QIAN, H.-Z. XU AND Y.-M. ChU, Sharp power mean bounds for two Sándor-Yang means, Rev. R. Acad. Cienc. Exactas Fís. Nat. Ser. A Mat. RACSAM, 113, 3 (2019), 2627-2638.

[27] H.-J. HU AND L.-Z. LIU, Weighted inequalities for a general commutator associated to a singular integral operator satisfying a variant of Hörmander's condition, Math. Notes, 101, 5-6 (2017), 830840.

[28] H.-J. Hu AND X.-F. Zou, Existence of an extinction wave in the Fisher equation with a shifting habitat, Proc. Amer. Math. Soc., 145, 11 (2017), 4763-4771.

[29] C.-X. Huang And J.-D. CaO, Stochastic dynamics of nonautonomous Cohen-Grossberg neural networks, Abstr. Appl. Anal., 2011 (2011), Article ID 297147, 17 pages.

[30] C.-X. Huang, S. Guo And L.-Z. LiU, Boundedness on Morrey space for Toeplitz type operator associated to singular integral operator with variable Calderón-Zygmund kernel, J. Math. Inequal., 8 , 3 (2014), 453-464.

[31] T.-R. HuAng, B.-W. HAN, X.-Y. MA AND Y.-M. ChU, Optimal bounds for the generalized EulerMascheroni constant, J. Inequal. Appl., 2018 (2018), Article 118, 9 pages.

[32] C.-X. Huang, H.-F. KuAng, X.-H., Chen And F.-H. Wen, An LMI approach for dynamics of switched cellular neural networks with mixed delays, Abstr. Appl. Anal., 2013 (2013), Article ID 870486, 8 pages.

[33] C.-X. HUANG AND B.-W. LiU, New studies on dynamic analysis of inertial neural networks involving non-reduced order method, Neurocomputing, 325, 24 (2019), 283-287.

[34] C.-X. HuAnG, B.-W. LiU, X.-M. Tian, L.-S. YANG AND X.-X. Zhang, Global convergence on asymptotically almost periodic SICNNs with nonlinear decay functions, Neural Process. Lett., 49, 2 (2019), 625-641.

[35] C.-X. Huang, C.-L. Peng, X.-H. Chen And F.-H. Wen, Dynamics analysis of a class of delayed economic model, Abstr. Appl. Anal., 2013 (2013), Article ID 962738, 12 pages.

[36] C.-X. Huang, Y.-C. Qian, L.-H. Huang And R. P. Agarwal, Dynamical behaviors of a foodchain model with stage structure and time delays, Adv. Difference Equ., 2018 (2018), Article 186, 26 pages. 
[37] T.-R. HuAng, S.-Y. TAN, X.-Y. MA And Y.-M. CHU, Monotonicity properties and bounds for the complete p-elliptic integrals, J. Inequal. Appl., 2018 (2018), Article 239, 11 pages.

[38] C.-X. HuAng, Z.-C. YAnG, T.-S. Y i And X.-F. ZHou, On the basins of attraction for a class of delay differential equations with non-monotone bistable nonlinearities, J. Differential Equations, 256, 7 (2014), 2101-2114.

[39] C.-X. HuAng AND H. ZHANG, On Periodicity of non-autonomous inertial neural networks involving proportional delays and non-reduced order method, Int. J. Biomath., 12, 2 (2019), Article ID 1950016, 13 pages.

[40] C.-X. Huang, H. Zhang And L.-H. Huang, Almost periodicity analysis for a delayed Nicholson's blowflies model with nonlinear density-dependent mortality term, Commun. Pure Appl. Anal., 18 (2019), 3337-3349.

[41] Y.-J. JiAng AND J.-T. MA, Spectral collocation methods for Volterra-integro differential equations with noncompact kernels, J. Comput. Appl. Math., 244 (2013), 115-124.

[42] Y.-J. JIANG AND X.-J. XU, A monotone finite volume method for time fractional Fokker-Planck equations, Sci. China Math., 62, 4 (2019), 783-794.

[43] Y. Khurshid, M. Adil Khan, Y.-M. Chu And Z. A. Khan, Hermite-Hadamard-Fejér inequalities for conformable fractional integrals via preinvex functions, J. Funct. Spaces, 2019 (2019), Article ID 3146210, 9 pages.

[44] R. KLÉn, M. VuORUnen And X.-H. ZHAng, Inequalities for the generalized trigonometric and hyperbolic functions, J. Math. Anal. Appl., 409, 1 (2014), 521-529.

[45] J.-L. Li, G.-Y. SUn AND R.-M. ZHANG, The numerical solution of scattering by infinite rough interfaces based on the integral equation method, Comput. Math. Appl., 71, 7 (2016), 1491-1502.

[46] X.-F. LI, G.-J. TANG AND B.-Q. TANG, Stress field around a strike-slip fault in orthotropic elastic layers via a hypersingular integral equation, Comput. Math. Appl., 66, 11 (2013), 2317-2326.

[47] J. LI, Y.-Y. YANG AND D.-X. XIE, On the analysis and application of an ion size-modified PoissonBoltzmann equation, Nonlinear Anal. Real World Appl., 47 (2019), 188-203.

[48] P. LindqVist, Some remarkable sine and cosine functions, Ricerche Mat., 44, 2 (1995), 269-290.

[49] P. Lindqvist And J. Peetre, $p$-arclength of the q-circle, Math. Student, 72, 1-4 (2003), $139-145$.

[50] Y.-C. LIU AND J. WU, Fixed point theorems in piecewise continuous function spaces and applications to some nonlinear problems, Math. Methods Appl. Sci., 37, 4 (2014), 508-517.

[51] Z.-Y. LIU, N.-C. WU, X.-R. QIN AND Y.-L. ZHANG, Trigonometric transform splitting methods for real symmetric Toeplitz systems, Comput. Math. Appl., 75, 8 (2018), 2782-2794.

[52] Z.-Y. LIU, Y.-L. ZHANG, J. SANTOS ADN R. RALHA, On computing complex square roots of real matrices, Appl. Math. Lett., 25, 10 (2012), 1565-1568.

[53] J.-Y. PENG AND Y. ZHANG, Heron triangles with figurate number sides, Acta Math. Hungar., 157, 2 (2019), 478-488.

[54] W.-M. Qian, Z.-Y. HE, H.-W. Zhang AND Y.-M. CHU, Sharp bounds for Neuman means in terms of two-parameter contraharmonic and arithmetic mean, J. Inequal. Appl., 2019 (2019), Article 168, 13 pages.

[55] W.-M. QIAn, H.-Z. XU AND Y.-M. CHU, Improvements of bounds for the Sándor-Yang means, J. Inequal. Appl., 2019 (2019), Article 73, 8 pages.

[56] W.-M. QIAN, Y.-Y. YANG, H.-W. ZHANG AND Y.-M. CHU, Optimal two-parameter geometric and arithmetic mean bounds for the Sándor-Yang mean, J. Inequal. Appl., 2019 (2019), Article 287, 12 pages.

[57] S. Rashid, M. A. Noor, K. I. Noor, F. Safdar And Y.-M. Chu, Hermite-Hadamard type inequalities for the class of convex functions on time scale, Math., 2009, 7 (2019), Article 956, 20 pages, DOI:10.3390/math7100956.

[58] Y.-Q. Song, M. Adil Khan, S. Zaheer Ullah and Y.-M. Chu, Integral inequalities involving strongly convex functions, J. Funct. Spaces, 2018 (2018), Article ID 6595921, 8 pages.

[59] Y.-X. TAN, C.-X. HuAng, B.-Sun And T. WANG, Dynamics of a class of delayed reaction-diffusion systems with Neumann boundary condition, J. Math. Anal. Appl., 458, 2 (2018), 1115-1130.

[60] Y.-X. TAN, K. JiAng, Existence and global exponential stability of almost periodic solution for delayed competitive neural networks with discontinuous activations, Math. Methods Appl. Sci., 39, 11 (2016), 2821-2839.

[61] W.-S. TANG AND Y.-J. Sun, Construction of Runge-Kutta type methods for solving ordinary differential equations, Appl. Math. Comput., 234 (2014), 179-191. 
[62] W.-S. TAng And J.-J. Zhang, Symplecticity-preserving continuous-stage Runge-Kutta-Nyström methods, Appl. Math. Comput., 323 (2018), 204-219.

[63] Z.-L. Tian, Y. LiU, Y. Zhang, Z.-Y. LiU AND M.-Y. Tian, The general inner-outer iteration method based on regular splittings for the PageRank problem, Appl. Math. Comput., 356 (2019), 479-501.

[64] W.-S. WANG, On A-stable one-leg methods for solving nonlinear Volterra functional differential equations, Appl. Math. Comput., 314 (2017), 380-390.

[65] W.-S. WANG AND Y.-Z. ChEn, Fast numerical valuation of options with jump under Merton's model, J. Comput. Appl. Math., 318 (2017), 79-92.

[66] W.-S. WANG, Y.-Z. CHEN AND H. FENG, On the variable two-step IMEX BDF method for parabolic integro-differential equations with nonsmooth initial data arising in finance, SIAM J. Numer. Anal., 57, 3 (2019), 1289-1317.

[67] J.-F. WANG, X.-H. Chen AND L.-H. HuAng, The number and stability of limit cycles for planar piecewise linear systems of node-saddle type, J. Math. Anal. Appl., 469, 1 (2019), 405-427.

[68] M.-K. Wang, H.-H. ChU And Y.-M. ChU, Precise bounds for the weighted Hölder mean of the complete p-elliptic integrals, J. Math. Anal. Appl., 480, 2 (2019), Article ID 123388, 9 pages, DOI: 10.1016/j.jmaa.2019.123388.

[69] M.-K. WANG, Y.-M. CHU AND W. ZhANG, Monotonicity and inequalities involving zero-balanced hypergeometric function, Math. Inequal. Appl., 22, 2 (2019), 601-617.

[70] M.-K. WANG, Y.-M. ChU AND W. ZHANG, Precise estimates for the solution of Ramanujan's generalized modular equation, Ramanujan J., 49, 3 (2019), 653-668.

[71] T. WANG AND H. GUo, Existence and nonexistence of nodal solutions for Choquard type equations with perturbation, J. Math. Anal. Appl., 480, 2 (2019), Article ID 123438, 20 pages, DOI: 10.1016/j.jmaa.2019.123438.

[72] J.-F. WAng, C.-X. HuAng And L.-H. HuAng, Discontinuity-induced limit cycles in a general planar piecewise linear system of saddle-focus type, Nonlinear Anal. Hybrid Syst., 33 (2019), 162178.

[73] J.-L. WANG, W.-M. QIAN, Z.-Y. HE AND Y.-M. CHU, On approximating the Toader mean by other bivariate means, J. Funct. Spaces, 2019 (2019), Article ID 6082413, 7 pages.

[74] M.-K. WANG, W. ZhANG AND Y.-M. CHU, Monotonicity, convexity and inequalities involving the generalized elliptic integrals, Acta Math. Sci., 39B, 5 (2019), 1440-1450.

[75] S.-H. WU AND Y.-M. ChU, Schur m-power convexity of generalized geometric Bonferroni mean involving three parameters, J. Inequal. Appl., 2019 (2019), Article 57, 11 pages.

[76] C.-E. XiaO, J.-B. LiU AND Y.-L. LiU, An inverse pollution problem in porous media, Appl. Math. Comput., 218, 7 (2011), 3649-3653.

[77] D.-X. XIE AND J. LI, A new analysis of electrostatic free energy minimization and Poisson-Boltzmann equation for protein in ionic solvent, Nonlinear Anal. Real World Appl., 21 (2015), 185-196.

[78] H.-Z. XU, Y.-M. ChU AND W.-M. QIAN, Sharp bounds for the Sándor-Yang means in terms of arithmetic and contra-harmonic means, J. Inequal. Appl., 2018 (2018), Article 127, 13 pages.

[79] Z.-H. YANG, W.-M. QIAN, Y.-M. ChU AND W. ZHANG, On rational bounds for the gamma function, J. Inequal. Appl., 2017 (2017), Article 210, 17 pages.

[80] S. Zaheer Ullah, M. Adil Khan and Y.-M. ChU, Majorization theorems for strongly convex functions, J. Inequal. Appl., 2019 (2019), Article 58, 13 pages.

[81] S. Zaheer Ullah, M. Adil Khan and Y.-M. ChU, A note on generalized convex functions, J. Inequal. Appl., 2019 (2019), Article 291, 10 pages.

[82] S. Zaheer Ullah, M. Adil Khan, Z. A. Khan and Y.-M. Chu, Integral majorization type inequalities for the functions in the sense of strong convexity, J. Funct. Spaces, 2019 (2019), Article ID 9487823, 11 pages.

[83] L. ZhANG AND S.-Y. JiAn, Further studies on the Wei-Yao-Liu nonlinear conjugate gradient method, Appl. Math. Comput., 219, 14 (2013), 7616-7621.

[84] T.-H. ZHAO, Y.-M. CHU AND H. WANG, Logarithmically complete monotonicity properties relating to the gamma function, Abstr. Appl. Anal., 2011 (2011), Article ID 896483, 13 pages.

[85] W.-J. ZHOU, On the convergence of the modified Levenberg-Marquardt method with a nonmonotone second order Armijo type line search, J. Comput. Appl. Math., 239 (2013), 152-161. 
[86] X.-S. ZHOU, Weighted sharp function estimate and boundedness for commutator associated with singular integral operator satisfying a variant of Hörmander's condition, J. Math. Inequal., 9, 2 (2015), $587-596$.

[87] W.-J. Zhou, AND X.-L. Chen, On the convergence of a modified regularized Newton method for convex optimization with singular solutions, J. Comput. Appl. Math., 239 (2013), 179-188.

[88] W.-J.ZHOU AND F. WANG, A PRP-based residual method for large-scale monotone nonlinear equations, Appl. Math. Comput., 261 (2015), 1-7.

[89] Q.-X. ZHU, C.-X. HUANG AND X.-S. YANG, Exponential stability for stochastic jumping BAM neural networks with time-varying and distributed delays, Nonlinear Anal. Hybrid Syst., 5, 1 (2011), 52-77. 